\title{
PREDICTION AND SURVEY OF APPLE PESTS AND DISEASES IN BÁCS-KISKUN COUNTY IN 2014
}

\author{
János ÁGOSTON ${ }^{*}$ \\ 1 John von Neumann University, Faulty of Horticulture and Rural Development, Department of Agriculture. \\ 6000 Kecskemét, Mészöly Gyula tér 1-3. Hungary \\ https://doi.org/10.47833/2020.2.AGR.039
}

\author{
Keywords: \\ Erwinia amylovora \\ MARYBLYT \\ Venturia inaequalis \\ Podosphaera leucotricha \\ Cydia pomonella

\section{Article history:} \\ Received 15 May 2020 \\ Revised 20 May 2020 \\ Accepted 25 May 2020
}

\begin{abstract}
Apple is the most important fruit crop in Hungary besides grape. In 2014 the total growing area was 33260 ha, which is 41,76\% of the total fruit orchards of the country. There are several pests and diseases attacking apple trees, the 3 most important diseases are fire blight (Erwinia amylovora), apple scab (Venturia anaequalis) and powdery mildew (Podosphaera leucotricha). From the pests the most important is codling moth (Cydia pomonella). Fortunately scientists and companies are working hard to provide decision making systems to help growers worldwide to predict pest occurrence and advising them about the timing of their application of pesticides to reduce their impact on the environment and enabling them to provide healthier food. Here I would like to provide an overview of some of the important pests of apple, their occurrence in 2014 and models used to predict their appearance.
\end{abstract}

\section{Introduction}

Apple is the most important fruit crop in Hungary besides grape. In 2014 the total growing area was 33260 ha, which is $41,76 \%$ of the total fruit orchards of the country [37].

Prediction of horticultural pests and diseases are also greatly important to reduce the environmental impact of the sector by more accurate timing of application of pesticides. The first record of a prediction model of horticultural diseases in Hungary was in 1913 described by ISTVÁNFFI and PÁLINKÁs. They published their findings about the temperature dependent appearance of grape downy mildew (Plasmopara viticola) symptom development which is still used today [22].

\subsection{Fire blight}

Fire blight's causative agent is Erwinia amylovora BURR. (WINSLOW) - a bacterium - which was first found and reported from Hungary from Nyárlörinc at the $25^{\text {th }}$ of April 1996 from two neighboring apple orchards [12]. MÁRIA HEVESI published her findings of the first report of the pathogen in 1996 [19]. At the time the authorities tried to eradicate the pest by cutting down and burning the affected orchards and all the host plants in the $3 \mathrm{~km}$ wide buffer zone [12]. Despite the strict quarantine measures the disease occurred in 297 more sites in 1996 at a total of 242 ha [13]. In 1997 the disease spread further to a total of 1195 ha, which devastated both growers and hobby gardeners [14]. The pathogen overwinters in cancerous wounds which become active when sap flow starts in spring.

MARYBLYT has been reported as a reliable model for the prediction of fire blight in Hungary [5, $6,34,35]$. The 4.3 version of the program were given to the pathology and prognostic experts of all

Corresponding author. Tel.: +36 76 517-726

E-mail address: agoston.janos@kvk.uni-neumann.hu 
the 20 Plant Protection Stations' of the country and used successfully ever since in their successor institutions even today.

MARYBLYT calculates the epiphytic infection potential (EIP), which is an indicator of infection risk, it also gives information of the potential risk for infection [4, 23, 24, 30]. Generally an EIP of 100 means there is a risk of infection, as a rule of thumb about $10 \%$ of the open flowers may become infected. Besides flower blight, the program can predict the development of other symptoms like shoot-, canker- and trauma blight [31].

\subsection{Apple scab}

Venturia inaequalis - the causative agent of apple scab - is an Ascomycetes fungi. The sexual form overwinters with pseudothecia. Ascospores disperse in spring usually after petal fall, when the leaves are expanding. After infection $0,5-1 \mathrm{~cm}$ wide yellowish green spots develop which slightly bulge out from the leaf surface. Soon after the appearance of the spots dark mycelia with conidiophores develop on the surface of the spot giving rise to the vegetative form Spilocea pomi. These symptoms can occur on the fruit too. Under the conidiophores the tissue becomes necrotic, scabs develop which gave the common name of the pathogen [1, 3, 16-18, 20, 21, 25, 32].

\subsection{Powdery mildew}

Powdery mildew of apple is caused by Podosphaera leucotricha. The pathogen normally overwinters with epiphytic mycelia on the twigs and in buds, seldom with its sexual propagating part kazmothecia. When leaves start do develop in spring from the infected bud the whole shoot becomes infected and covered with mycelia. This is called primary infection. As leaves expand the mycelia starts forming oidium type conidia which can be dispersed with wind and start secondary infections. These secondary infections grow a few centimeters wide at first, but if left untreated they expand towards the buds and infect them. On the fruits, below the mycelia the epidermis dies, as the fruit grows net like russetting occurs [1, 3, 16-18, 20, 21, 25, 32].

All 3 diseases have global distribution [8].

\subsection{Codling moth}

Codling moth (Cydia pomonella syn. Laspeyresia pomonella) is an important pest of the fruits. The larvae first feeds on the surface of the fruit or neighboring leaves, from $L_{2}$ the larvae burrows into the fruit and eats the seeds. In early stages of fruit development the attacked fruit abscises, later the fruit stays on the tree. The entering and exiting wounds are perfect places for infection with Monilinia fructigena, and at fruit ripening bees and wasps are collecting sweet juice from them. Under Hungarian climatic conditions the pest can have 2 or 3 generations a year. It overwinters in $L_{5}$ stage larva, which makes a cocoon on the trunk or branches of the tree [3,18, 20, 25, 26, 32].

\section{Methods}

Experiments and observations were made in Bács-Kiskun County in 2013 and 2014. Meteorological data (daily min, daily max, precipitation) were collected from Baja, Kecskemét, Kelebia, Soltvadkert and Tass at $2 \mathrm{~m}$ height.

Host plant phenology and disease data were retrieved from the Plant Protection Information System (NIR) [29] and from the reports of district plant protection inspectors of the Government Office of Bács-Kiskun County. The reporting of pest severity was carried out by the protocols of EPPO and Agricultural Administrative Agency (MgSZH) [7, 9-11, 27, 28].

Symptom appearance prediction of fire blight and generation of graphs were carried out with MARYBLYT v7.1, with settings for apple [24, 33]. This disease was observed and predicted in 'Jonathan' and 'Summer Apple' orchards in Kecskemét.

Infection pressure and prediction of powdery mildew and scab infection dates were predicted with LUFFT HP-100 meteorological and disease prediction station [15].

Sex pheromone trapping of codling moth males were carried out with CSALOMON traps at Kecel. To predict generations the model of TAMÁS HEGYI was used, which is the adaptation of the models of ALSTON et al. [2] and WILLIAMS [36] to Hungarian conditions. His model is based on $10^{\circ} \mathrm{C}$ base temperature, first egg laying is between 55-60 Degree Days (DD), massive egg laying 85-90 
DD, emergence of first instar larvae 150 DD, emergence of adults of the next generation 640-650 DD. All figures - except for fire blight - were created with MS Excel, and annotated with MS Power Point programs.

\section{Results}

\subsection{Fire blight}

In 2014 the EIP did not reach 100 during the flowering of the 2 assessed cultivars, thus blossom blight was not predicted and have not been observed in these orchards.

In the case of 'Jonathan' apples cankers were activated on the $25^{\text {th }}$ of March, bacterial exudates appeared on $12^{\text {th }}$ of May. Shoot blight caused by canker activation appeared on $27^{\text {th }}$ of May. Shoot blight appeared on $9^{\text {th }}$ of June. These observations coincide with the predictions of the program (Figure 1.).

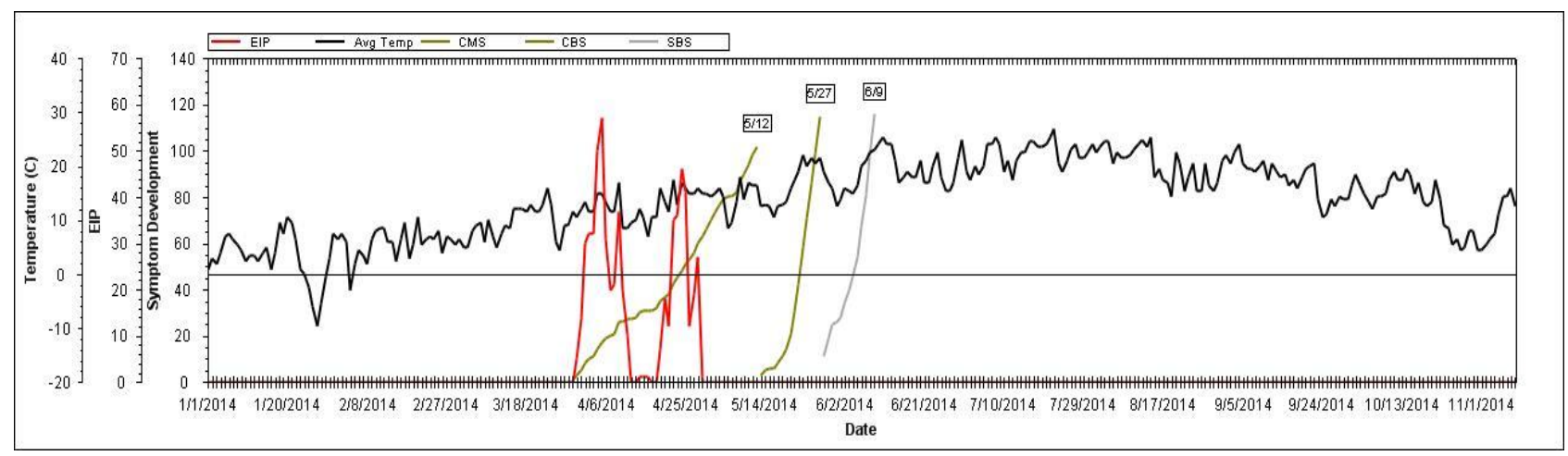

Figure 1. Prediction of fire blight symptoms in Jonathan apples by MARYBLYT V7.1

(CMS: cancer margin symptoms, CBS: cancer blight symptoms, SBS: shoot blight symptoms)

In 'Summer Apple' cankers were activated on the $17^{\text {th }}$ of March, bacterial exudates appeared on $9^{\text {th }}$ of May. Shoot blight caused by canker activation appeared on $25^{\text {th }}$ of May. Shoot blight appeared on $7^{\text {th }}$ of June. These observations coincide with the predictions of the program (Figure 2.).

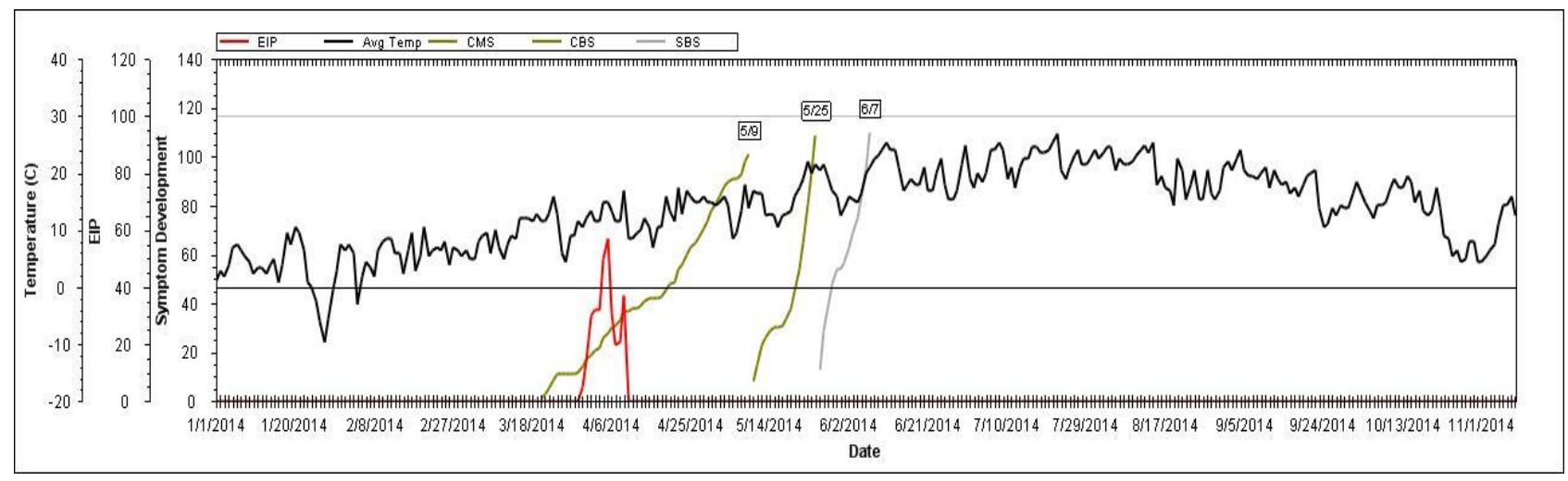

Figure 2. Prediction of fire blight symptoms in Summer Apples by MARYBLYT V7.1

\subsection{Apple scab}

In 2013 the severity of apple scab on leaves were low. In mid-May $90 \%$ of the orchards were healthy, $13 \%$ slightly, $5 \%$ medium and only $1 \%$ severely infected. By mid-August $80 \%$ of the orchards were healthy, and $20 \%$ were slightly infected. By 2014 mid-May $64 \%$ of the orchards were healthy, $22 \%$ slightly and $11 \%$ medium severely infected (Figure 3.).

In 2013 the severity of apple scab on fruits were low. In early June $68 \%$ of the fruits were healthy, $21 \%$ slightly, $11 \%$ medium and only $1 \%$ severely infected, by mid-August $75 \%$ of the fruits were healthy, and $16 \%$ were slightly, $8 \%$ medium and $1 \%$ severely infected. By 2014 early June 
$40 \%$ of the fruits were healthy, $40 \%$ slightly, $18 \%$ medium and $2 \%$ medium severely infected. By mid-August $66 \%$ of the fruits were healthy, $28 \%$ slightly and $6 \%$ medium infected (Figure 4 .).

In 2014 the LUFFT machine predicted 33 infection days for apple scab. From bud break to leaf fall this means an average of 6.5 days between infections (Figure 5.). This is an unusual high number, normally it is between $10-14$ days.

Apple scab infection of leaves in Bács-Kiskun County, 2013-2014

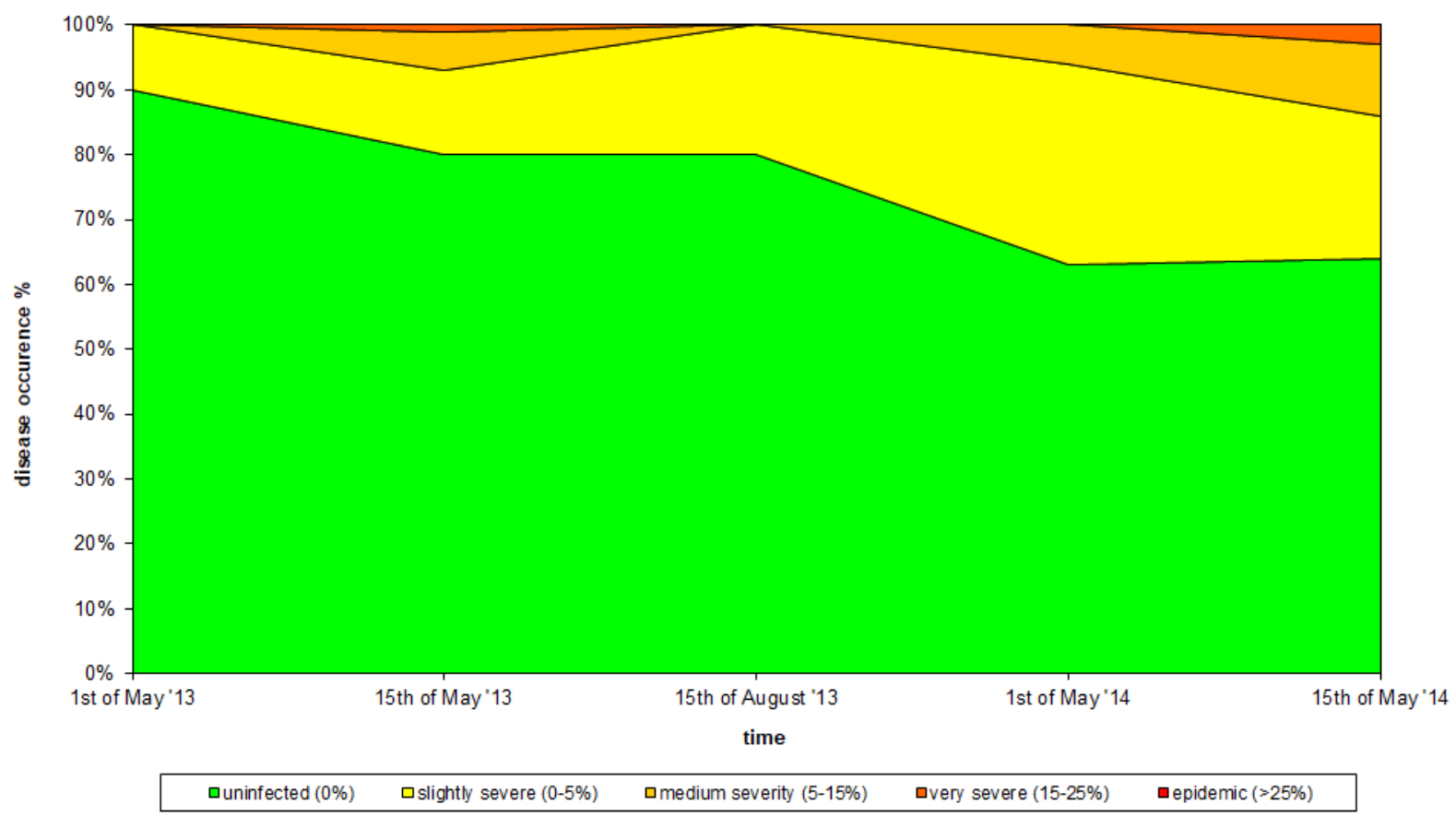

Figure 3. Scab infection of apple leaves in 2013 and 2014.

Apple scab infection of fruits in Bács-Kiskun County, 2013-2014

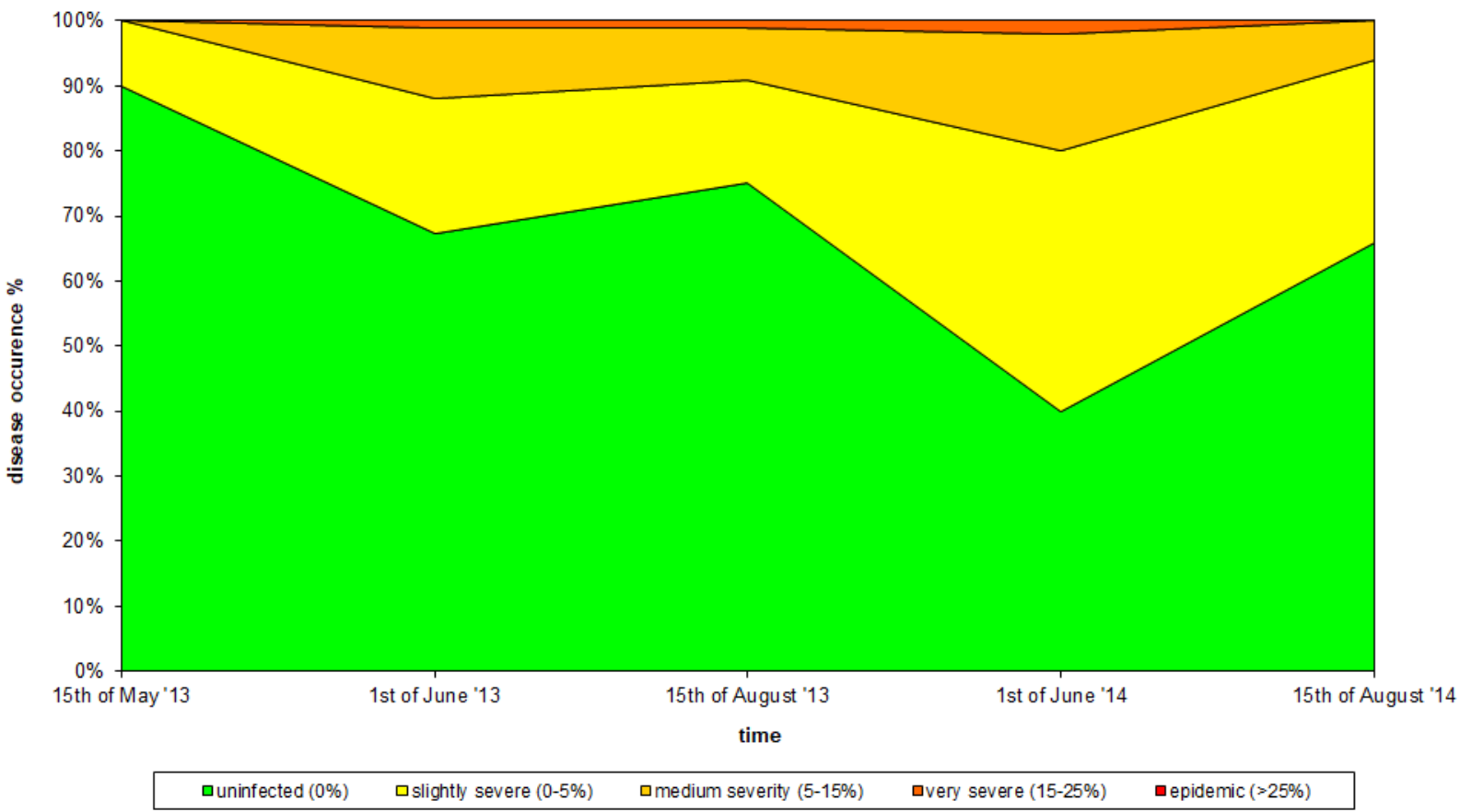

Figure 4. Scab infection of apple fruits in 2013 and 2014. 


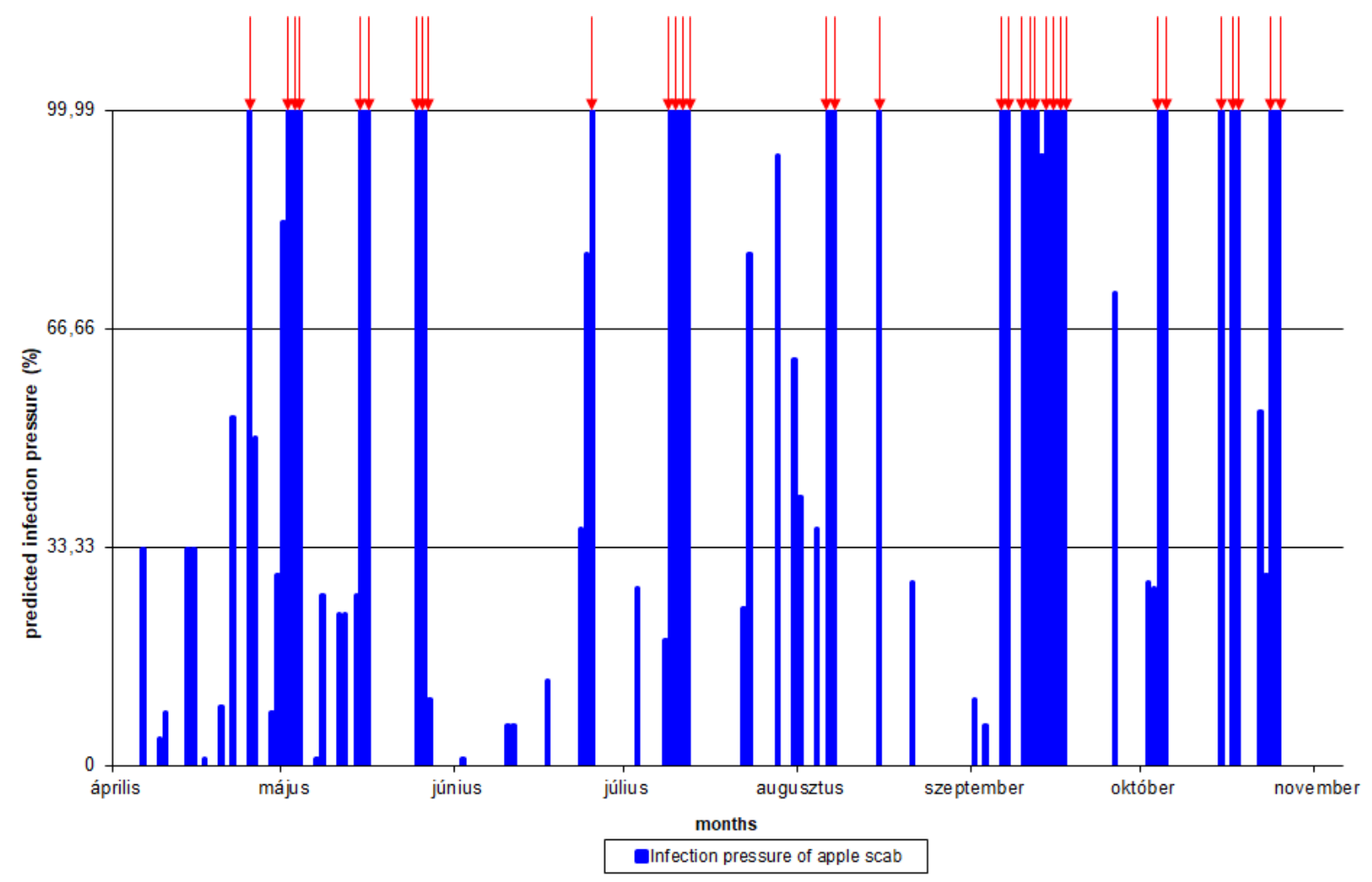

Figure 5. Apple scab infection pressure in 2014 predicted by LUFFT machine. Red arrows indicate $100 \%$ infection probability.

\subsection{Powdery mildew}

At the end of March 2013 powdery mildew infection of shoots and leaves were low. $85 \%$ were healthy and $15 \%$ were slightly infected (Figure 6.). By the middle of June some parts of the county faced an epidemic. At this time $84 \%$ were healthy, $14 \%$ showed slight, $1 \%$ medium, $1 \%$ high infection and $1 \%$ epidemic levels. In 2014 mid-May powdery mildew seemed to get out of the hands of growers. Only $68 \%$ were healthy, $21 \%$ has slight, $8 \%$ medium and $4 \%$ high infection, which bounced back by mid-August. Then $85 \%$ were healthy, $13 \%$ showed slight, and only $2 \%$ showed medium infection (Figure 7.).

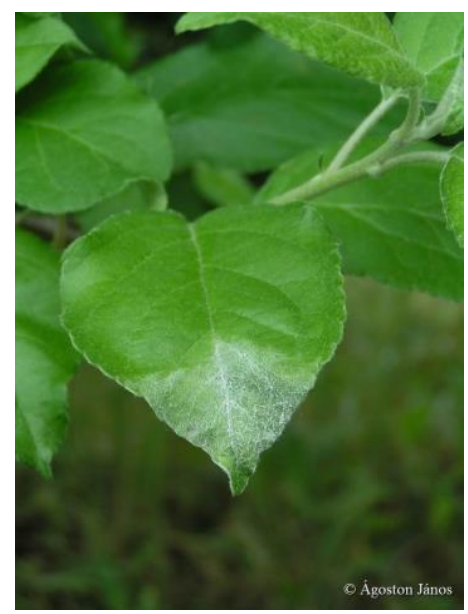

Figure 6. Slight powdery mildew infection on an apple leaf (2014).

If the infection pressure is over $66 \%$ there is a very high probability of powdery mildew infection. From beginning of April till the end of October 2014 the number of days when infection pressure was over $66 \%$ was 148 days, which is $69.16 \%$ of the vegetative period (Figure 8 .). 


\section{Apple powdery mildew on shoots and leaves, 2013-2014}

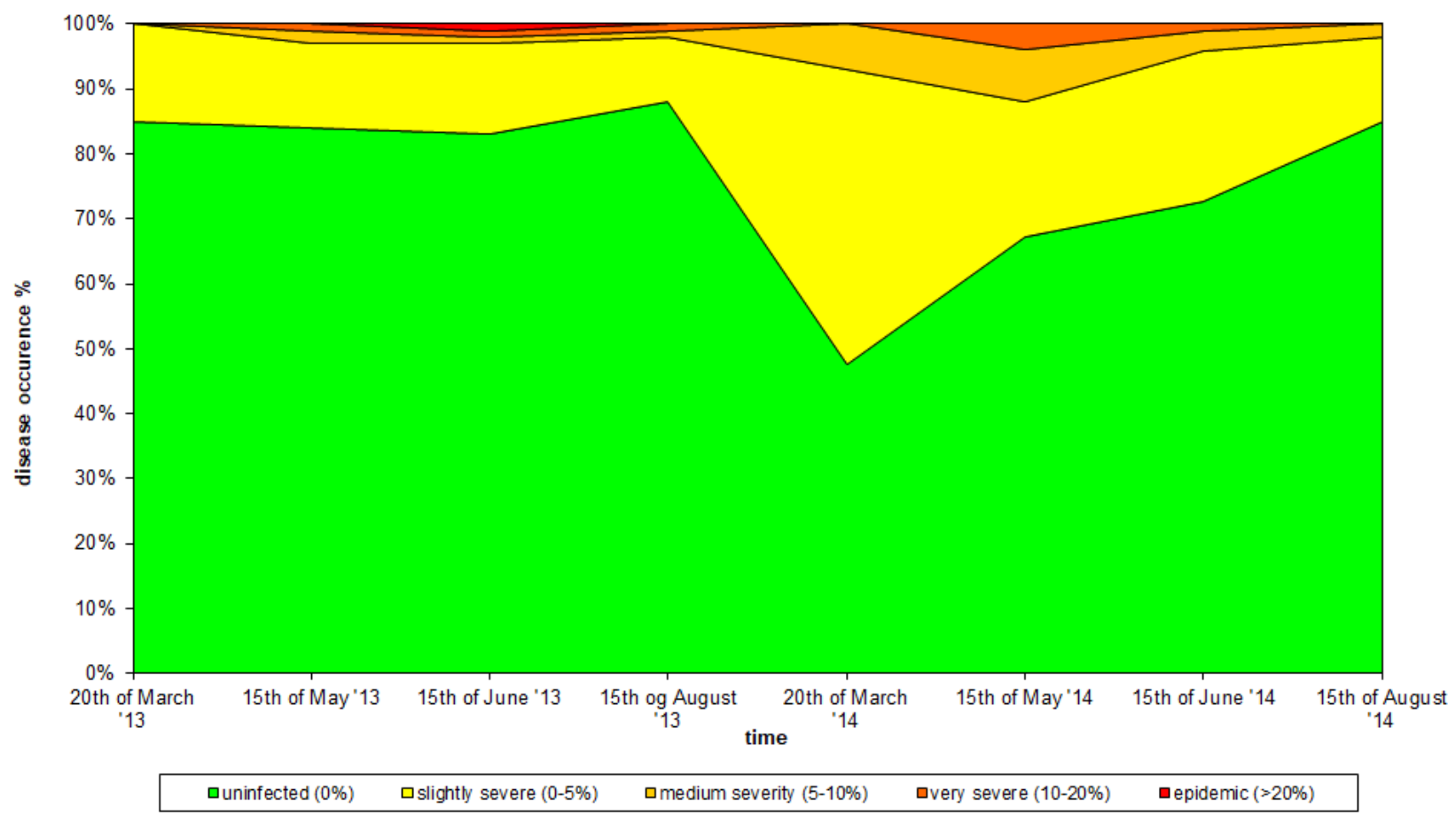

Figure 7. Powdery mildew infection of apple shoots and leaves in 2013 and 2014.

\section{Apple powdery mildew infection dynamics, 2014}

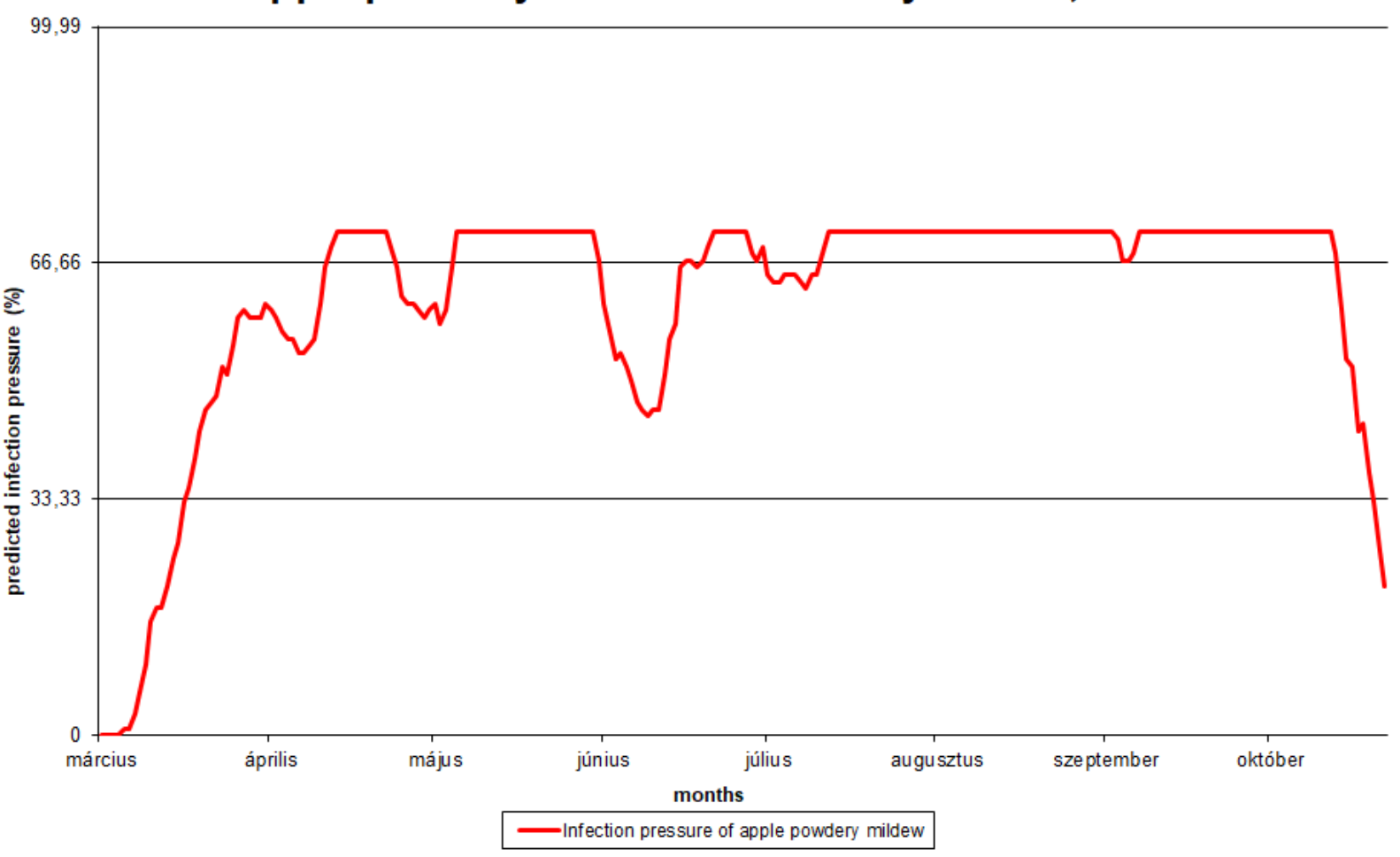

Figure 8. Apple powdery mildew infection pressure in 2014 predicted by LUFFT machine. 


\subsection{Codling moth}

This pest has 2 to 3 generations in a year depending on weather conditions. Most of the years it has an erratic flight so it is very hard for growers to time the application of chemicals to hit the first instar larvae. By looking at the captures of pheromone traps from Kecel (Figure 9.), one would draw the conclusion that the flight of the first generation ended $11^{\text {th }}$ of June, the second generation's flight ended $7^{\text {th }}$ of July and the last generation started at $31^{\text {st }}$ of July.

Using the model of TAMÁS HEGYI the second generation emerged on the $2^{\text {nd }}$ of July and the third on the $4^{\text {th }}$ of September. Mass emergence of the larvae was on the $21^{\text {st }}$ of May -5 weeks later than the emergence of the first generation. Mass emergence of the second generation was on the $21^{\text {st }}$ of July.

\section{Kecel 2014}

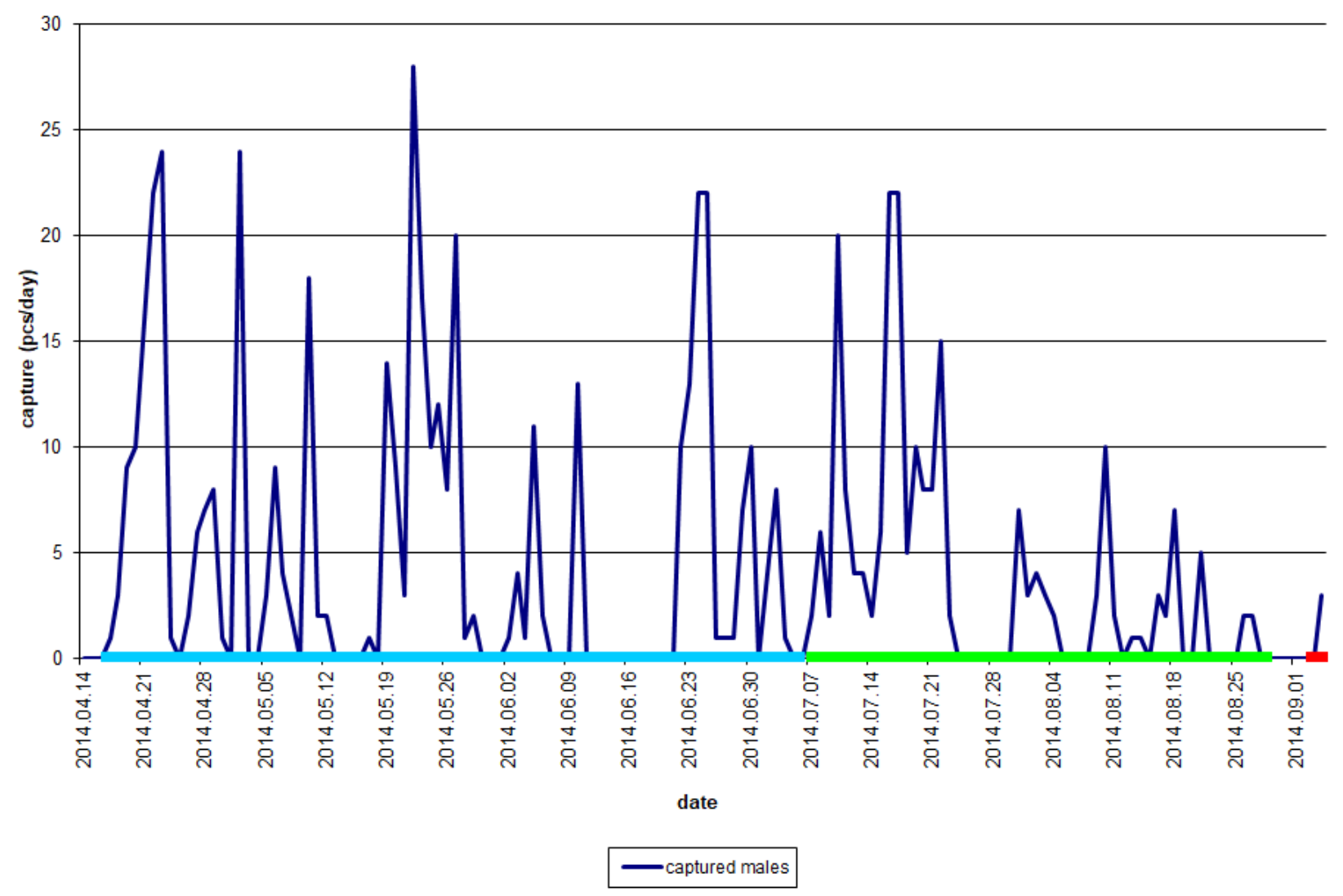

Figure 9. Sex pheromone captures and generations of codling moth in 2014 at Kecel.

Blue bar indicates the flight of $1^{\text {st }}$ generation, green bar $2^{\text {nd }}$ generation, red bar $3^{\text {rd }}$ generation.

\section{Discussion and Conclusions}

In each tested cultivar the MARYBLYT model predicted the appearance of blight symptoms accurately.

Apple scab disease severity on both leaves and fruits were higher in 2014, but never reached epidemic levels, tough the average days between infections were 6.5 days compared to the usual 10-14 days. Infection days coincide with rainy days. 2014 had 66 of rainy days from beginning of April to end of October, while 2013 had only 45 rainy days in the same interval. $36 \%$ of total disease occurrence in mid-May and the very high infection rate of fruits in early June (60\%) is the result of the survival of the vast majority of perithecia of the 2013/2014 winter, favorable weather conditions and the neglect of early preventative and curative measures. Because of the very high disease 
occurrence on fruits growers applied almost $50 \%$ more chemicals to protect the rest of the remaining crop.

In the case of powdery mildew disease occurrence was much higher in 2014 as compared to 2013. $69.16 \%$ of the days in the growing season had a very high probability of mildew infection. The $32 \%$ disease occurrence in mid-May of 2014 is probably caused by the neglect of pruning out the infected twigs in dormancy.

Codling moth's flight are mostly erratic in Hungary. Application of insecticides bases solely on the captures of pheromone traps may not lead to the desired result. It is essential that growers signalize this pest with pheromone traps, but better timing of application with degree day models can be much more effective, more economical and more eco-friendly.

Application of Juvenal hormone analogues, molting disruptors or inhibitors of chitin biosynthesis can be more accurately timed based on the model of TAMÁs HEGYI.

\section{Acknowledgment}

l'd like to express my gratitude towards GÁBOR MEZÖ, TAMÁS HEGYI, for their observations and help, EDIT SZÜCS and BÁLINT BENEDECZKI for pheromone trap and meteorological data, and their help in assessment of the trials and assistance in the laboratory.

Thank you for the support of the research carried out in the framework of the EFOP-3.6.2-162017-00012 „Developing a functional, healthy and safe food product chain model from field to table in a thematic research network". The project is funded by the Hungarian State and the European Union, co-financed by the European Social Fund, and is part of the Széchenyi 2020 program.

\section{References}

[1] Agrios G. N. (2005) Plant pathology. Elsevier Academic press, Amsterdam. ISBN: 978-0-08-047378-9.

[2] Alston D., Murray M., Reding M. (2010) Codling Moth (Cydia pomonella). 7.

[3] Bálint J., Bognár S., Farkas K., et al. (1978) Kertészeti növényvédelem. Mezőgazdasági Kiadó, Budapest. ISBN: 963-230-380-6.

[4] Bonn W. G., Leuty T. (1993) An assessment of the MARYBLYT ${ }^{\mathrm{TM}}$ computer program for the prediction of fire blight in Ontario, Canada. Acta Hortic 145-152. https://doi.org/10.17660/ActaHortic.1993.338.20

[5] Bubán T., Sallai P., Varga A., Dorgai L. (2002) Investigation of the reliability of easy-to-use methods to predict Eerwinia amylovora infection risk in apple orchards. Acta Hortic 119-125. https://doi.org/10.17660/ActaHortic.2002.590.16

[6] Dewdney M. M., Biggs A. R., Turechek W. W. (2007) A statistical comparison of the blossom blight forecasts of MARYBLYT and Cougarblight with receiver operating characteristic curve analysis. Phytopathology 97:11641176. https://doi.org/10.1094/PHYTO-97-9-1164

[7] EPPO (2012) Conduct and reporting of efficacy evaluation trials, including good experimental practice. EPPO Bulletin 42:382-393. https://doi.org/10.1111/epp.2611

[8] EPPO (2020) EPPO Global Database (available online) https://gd.eppo.int.

[9] EPPO (1988) Guideline for the biological evaluation of insecticides - PP1/007(3) Cydia pomonella. EPPO Bulletin 18:613-619. https://doi.org/10.1111/j.1365-2338.1988.tb00097.x

[10] EPPO (1990) Guideline for the efficacy evaluation of fungicides - PP1/005(3) Venturia inaequalis and V. pyrina. EPPO Bulletin 20:425-433. https://doi.org/10.1111/j.1365-2338.1990.tb00166.x

[11] EPPO (1999) Guidelines for the efficacy evaluation of plant protection products - PP 1/69(3) Podosphaera leucotricha. EPPO Bulletin 29:285-289. https://doi.org/10.1111/j.1365-2338.1999.tb00834.x

[12] EPPO Reporting Service (1996) First report of Erwinia amylovora in Hungary. 1.

[13] EPPO Reporting Service (1997) Situation of fireblight in Hungary in 1996. 1.

[14] EPPO Reporting Service (1998) Situation of fireblight in Hungary in 1997. 1.

[15] G. Lufft Mess- und Regeltechnik GmbH. (1994) HP-100 használati utasítás. G. Lufft Mess- und Regeltechnik $\mathrm{GmbH}$.

[16] Glits M., Folk Gy. (1993) Kertészeti növénykórtan. Mezőgazda Kiadó, Budapest. ISBN: 978-963-7362-69-9.

[17] Glits M., Folk Gy. (2001) Kertészeti növénykórtan. Mezőgazda Kiadó, Budapest. ISBN: 978-963-286-297-2.

[18] Glits M., Horváth J., Kuroli G., Petróczi I. (eds) (1997) Növényvédelem. Mezőgazda Kiadó, Budapest. ISBN: 978-963-286-042-8.

[19] Hevesi M. (1996) Az Erwinia amylovora (Burill) Winslow et al. hazai megjelenése almán. Növényvédelem 32:225-228.

[20] Hluchý M., Ackermann P., Zacharda M., Laštůvka Z., Bagar M., Jetmarová E., Gáspár V., Szőke L., Plíšek B. (2007) A gyümölcsfák és a szőlő betegségei és kártevői. Biocont Laboratory Ltd. Brno-Slatina, CZ, Brno. ISBN: 978-80-901874-9-8. 
[21] Horst R. K. (2013) Westcott's Plant Disease Handbook. Springer Netherlands, Dordrecht. ISBN: 978-94-0072140-1. https://doi.org/10.1007/978-94-007-2141-8

[22] Lehoczky J., Reichart G. (1968) A szőlő védelme. Mezőgazdasági Kiadó, Budapest.

[23] Lightner G. W., Steiner P. W. (1990) Computerization of blossom blight prediction model. Acta Hortic 159-162. https://doi.org/10.17660/ActaHortic.1990.273.20

[24] Lightner G. W., Steiner P. W. (1992) Maryblyt ${ }^{\mathrm{TM}}$ : A computer model for predicting of fire blight disease in apples and pears. Computers and Electronics in Agriculture 7:249-260. https://doi.org/10.1016/S0168-1699(05)800237

[25] Maráczi L. (2013) Díszfák, díszcserjék védelme. Nyugat-dunántúli Díszfaiskolások Egyesülete, Szombathely. ISBN: 978-963-08-6992-8.

[26] Mészáros Z. (1993) Család: Sodrómolyok- Tortricidae. In: Jermy T, Balázs K (eds) A Növényvédelmi állattan kézikönyve 4/A. Akadémiai Kiadó, Budapest. pp. 202-434. ISBN: 978-963-05-5741-X.

[27] MgSzH (2004) Általános vizsgálati módszertan. Mezôgazdasági Szakigazgatási Hivatal, Budapest.

[28] MgSzH (2004) Fungicid és baktericid vizsgálati módszertan. Mezôgazdasági Szakigazgatási Hivatal, Budapest.

[29] Növény és Talajvédelmi Állomás (1990) NIR: Növényvédelmi Információs Rendszer. Növény és Talajvédelmi Állomás, Budapest.

[30] Steiner P. W. (1990) Predicting apple blossom infections by Erwinia amylovora using the MARYBLYT model. Acta Hortic 139-148. https://doi.org/10.17660/ActaHortic.1990.273.18

[31] Steiner P.W. (1990) Predicting canker, shoot and trauma blight phases of apple fire blight epidemics using the MARYBLYT model. Acta Hortic 149-158. https://doi.org/10.17660/ActaHortic.1990.273.19

[32] Tomiczek C., Cech T., Krahan H., Perny B., Hluchý M., Šefrová H. (2005) A díszfák betegségei és kártevői. Biocont Laboratory Ltd. Brno-Slatina, CZ, Brno. ISBN: 80-901874-6-3.

[33] Turechek W. W., Biggs A. R. (2018) Maryblyt 7.1: Windows application for apple fireblight predictive model. University of Maryland

[34] Végh A. (2012) Az almafélék tűzelhalásást okozó Erwinia amylovora hazai izolátumainak biológiai változatossága. PhD, Corvinus University of Budapest, Faculty of Horticultural Science, Department of Plant Pathology

[35] Vidhyasekaran P. (2004) Concise encyclopedia of plant pathology. C R C Press LLC Taylor \& Francis Group [distributor, Boca Raton; Florence. ISBN: 978-1-56022-942-1.

[36] Williams D. (2000) Codling Moth. 4.

[37] (2020) EUROSTAT (available online) https://ec.europa.eu/eurostat/data/database. 